\title{
Disastrous Flash Floods Triggered by Moderate to Minor Rainfall Events. Recent Cases in Coastal Benguela (Angola)
}

\author{
Pedro A. Dinis ${ }^{1} \mathbb{C}$, João Huvi ${ }^{2}$, Marina Cabral Pinto ${ }^{3, * \mathbb{C}}$ and Joel Carvalho ${ }^{4}$ \\ 1 Marine and Environmental Sciences Centre (MARE), Department of Earth Sciences, University of Coimbra, \\ Rua Sílvio Lima, 3030-790 Coimbra, Portugal; pdinis@dct.uc.pt \\ 2 Instituto Superior de Ciências da Educação de Benguela, Rua Silva Porto, \\ Caixa Postal 643-Benguela, Angola; hjoaohuvi@gmail.com \\ 3 Geobiotec Research Centre, Department of Geosciences, University of Aveiro, 3810-193 Aveiro, Portugal \\ 4 Marine and Environmental Sciences Centre (MARE), 3004-517 Coimbra, Portugal; \\ uc2011160007@student.uc.pt \\ * Correspondence: marinacp@ua.pt
}

check for updates

Citation: Dinis, P.A.; Huvi, J.; Cabral Pinto, M.; Carvalho, J. Disastrous Flash Floods Triggered by Moderate to Minor Rainfall Events. Recent Cases in Coastal Benguela (Angola). Hydrology 2021, 8, 73. https://doi.org/10.3390/ hydrology 8020073

Academic Editor:

Jorge Lorenzo-Lacruz

Received: 6 April 2021

Accepted: 29 April 2021

Published: 1 May 2021

Publisher's Note: MDPI stays neutral with regard to jurisdictional claims in published maps and institutional affiliations.

Copyright: (C) 2021 by the authors Licensee MDPI, Basel, Switzerland. This article is an open access article distributed under the terms and conditions of the Creative Commons Attribution (CC BY) license (https:/ / creativecommons.org/licenses/by/ $4.0 /)$.

\begin{abstract}
The present work focuses on two recent flash floods in coastal Benguela (Angola), both triggered by moderate rainfall but which had disastrous consequences for local populations (namely 71 deaths in 2015 and 17 in 2019). The research involved a regional survey to establish the effects of these floods combined with a geomorphological and socio-economic analysis of the most affected areas to understand the main forcing factors. The two flash floods produced major damage in restricted sectors within very small coastal catchments $\left(<16 \mathrm{~km}^{2}\right)$. The prevalence of fine-grained sedimentary rocks, relatively steep hills, thin soil cover, and vegetation scarcity are natural factors that promote surface runoff. However, socio-economic conditions are most likely the main reasons of flood damage. Namely, rapid population growth with poor planning and making use of low-quality construction materials, the high waste yields that are not properly managed and the absence of flood risk awareness. In the small valleys around the fast-growing cities of coastal Benguela, hazardous flash floods occur recurrently, even after moderate precipitation. Most affected areas are determined by local conditions that compromise drainage at the time of the rainfall event, being very difficult to predict.
\end{abstract}

Keywords: flood hazards; natural and anthropogenic context; informal settlements; sub-tropical SW Angola

\section{Introduction}

Floods are common natural disasters that cause severe damage in modern societies and affect both the wealthiest and the least developed countries. They accounted for nearly $50 \%$ of all weather-related disasters and affected 2.3 billion people worldwide between 1995 and 2015, a significant part residing in urban areas [1]. Coping with flash floods is a particularly difficult task. These floods are generally associated with intense rainfall of short duration that fall in small catchment areas causing sudden and violent occurrences [2]. Hence, flash floods are extremely hazardous. During recent decades, several researchers have been focused on the development of mitigation measures [3,4] and on systems for flash flood prediction and warning $[5,6]$.

The occurrence of flash floods is determined by several natural factors. They are usual in arid regions influenced by infrequent rainstorms that are responsible for sudden water flow in valleys that are otherwise dry [7-9]. Orographic features can also be crucial, namely the steep slopes that limit infiltration, e.g., [10,11], and the broadly circular catchment shapes that tend to be associated with torrential regimes, e.g., [12,13]. Other important factors are the impervious vs. permeable nature of bedrocks and the characteristics of their covering soil and vegetation [14-16]. Regardless of natural controls, the effects of flash 
floods are strongly influenced by land use. Urbanization is responsible for increasing impervious area in drainage basins, hence increasing runoff volume, intensity, and peak flow, while decreasing the lag time between the peaks of rainfall and generated runoff [17-20]. As with other natural disasters, the poorest fringes of the population living in informal settlements are the most vulnerable to flooding [21-24].

Recognizing the hazardous character of flash floods, several projects were developed in southern African countries aiming a better understanding of floods dynamics and the prevention and mitigation of their effects [25-27]. Investigations have involved the application of remote sensing data, namely for meteorological estimates, which can be very useful where regular in situ measurements are lacking [28-30]. As in other developing countries, informal settlements that surround fast-growing cities of Angola can be severely affected by flooding events. However, research on this topic has been limited, leaving the area fertile for huge damage, which has occurred recurrently in the Angolan Atlantic margin. On 11 March 2015, a rainstorm triggered a tragic flood in coastal Benguela. Most destruction happened in dry valleys of southern Lobito and surrounding housing districts. Available data provided by Lobito's municipality indicate that 71 lives were lost and at least 375 buildings were destroyed or severally damaged [31]. During the following days, normal activity in the Benguela province was profoundly disturbed and the flooding event received large attention in broadcasting news. Four years later, on 16 March, coastal Benguela was affected again by a tragic flash flood. This time approximately $20 \mathrm{~km}$ to the south, in Catumbela, causing 17 deaths, 28 injured and the collapse of 81 buildings.

In the present work, we describe the effects of these two events and discuss the factors that may be held responsible for the observed damage. The main points of interest are to (1) determine if the events were promoted by exceptional meteorological conditions, (2) establish the local vs. regional character of the floods, (3) discern the non-climatic natural variables that may promote flash floods, and (4) identify socio-economic features responsible for enhancing the effects of sporadic water flow. The investigation was performed using remote sensing data coupled with information that can be easily obtained in field survey by non-experts. It shows how the combination of these two sets of data can fill knowledge gaps in countries severely affected by flooding events where background data and technological tools are limited.

\section{Regional Setting}

\subsection{Geological and Orographic Features}

The Benguela margin belongs to a tectonic segment with high uplifting rates, contrasting with northern Angola of gentler relief [32]. This margin outcrops the Meso-Cainozoic Benguela Basin, which is associated with the opening of the South Atlantic, with diverse detrital and carbonate sedimentary units along with intercalations of evaporites and volcanic rocks near the base of the succession [32-34]. The onshore exposures of this basin extend for approximately $250 \mathrm{~km}$ along strike (parallel to coastline), with a maximum width of $25 \mathrm{~km}$. At Lobito-Catumbela latitude, the Benguela Basin is in general $<15 \mathrm{~km}$ in width and comprises mainly Cretaceous units (Figure 1). Sparse Pleistocene coastal terraces unconformably cover this Cretaceous succession (Figure 1). Costal geomorphology is also influenced by the Catumbela River (Figure 1), which extends for $\sim 240 \mathrm{~km}$ with a drainage area of $16,500 \mathrm{~km}^{2}$, reaching an elevation of almost $2000 \mathrm{~m}$. Its sediment loads contributed for the growth of the Catumbela delta, a Holocene coastal accumulation with a sub-aerial surface of approximately $20 \mathrm{~km}$ alongshore that lies below $10 \mathrm{~m}$ in elevation [35]. 

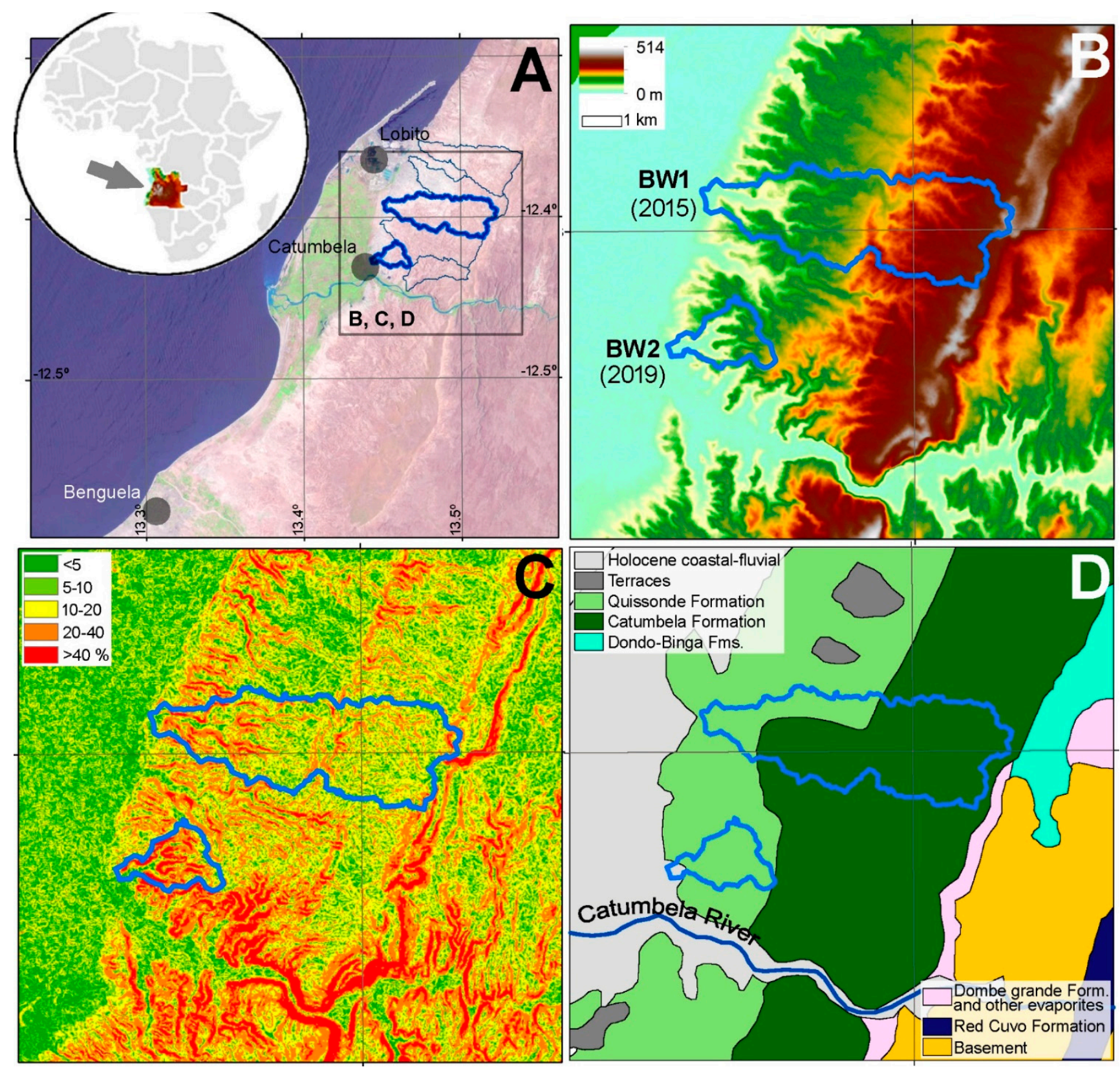

Figure 1. General features of the study area. (A) Location of the study area and affected catchments in SW Angola; other comparable coastal catchments are drawn with thinner line. Elevation (B) and slope (C) maps obtained with a Digital Elevation Model from SPOT. (D) Geological sketch redrawn from Guiraud and colleagues [32].

A staircase from the Holocene nearshore accumulations of low elevation to a narrow littoral ridge located $\sim 12 \mathrm{~km}$ inland (up to $500 \mathrm{~m}$ elevation) is shown by three high slope strips (Figure 1C) aligned in parallel to the regional coastline (i.e., NNE-SSW). These strips are closely linked to regional geology (Figure 1B). The lowest is placed at the boundary between the deposits of the Catumbela delta and the marls and limestones of the Quissonde Formation; the middle is at the contact between the Quissonde Formation and the sandy carbonates of the Catumbela Formation; the upper follows the contact of the Catumbela Formation with the underlying Dondo (sandstones and clays) and Binga (limestone-dominated) formations.

The Cretaceous sedimentary succession is densely incised by a valley net broadly perpendicular to regional strike. The valleys are incised on the Cretaceous basement and, except immediately after rain events, remain dry year-round. Valleys are $\sim 500 \mathrm{~m}$ wide 
and display relatively flat bottoms in downstream locations of the biggest rivers, but they become substantially narrower upstream, where they tend to be 100-200 $\mathrm{m}$ in width or no more than small gullies. Valley margins are step in the western edges of terraced areas and in upstream locations, commonly with elevation unevenness of $\sim 30-40$ m (Figure 1).

\subsection{Climate Conditions}

The climate in Benguela is influenced by the position of the Intertropical Convergence Zone. Meteorological conditions also depend on the Congo Air Boundary, a convergence zone that marks the transition between the Indian and Atlantic air masses, which controls seasonal variability e.g., [36,37]. The coastal region is strongly affected by the northflowing Benguela Current, which is responsible for low sea surface temperatures and low-humidity southerly winds [38]. Thus, annual rainfall in coastal Benguela is minor $(<300 \mathrm{~mm})$, contrasting with inland regions at similar latitude, where it can reach more than $1000 \mathrm{~mm}$. In turn, coastal areas are warmer $\left(\sim 24-25^{\circ} \mathrm{C}\right)$ than the higher elevation headlands of Catumbela $\left(\sim 17^{\circ} \mathrm{C}\right)$. Almost all rainfall falls between November and April, when temperatures also tend to be slightly higher.

Interannual climatic variability is conditioned by latitudinal shifts in the convergence zone between the cold Benguela Current and the warm Angola Current, the so-called Benguela Niña/Niño [39-42]. When it is displaced southward (Benguela Niño) sea surface temperatures in coastal Benguela are higher and several consecutive days of heavy rainfall may occur; displacement to lower latitudes (Benguela Niña) is associated with drier than average conditions. These events typically reach their maxima during March-April [40,41]. Overall, 2015 and 2019 were relatively dry years.

\subsection{Human Occupation}

The cities of Lobito and Catumbela have an urbanized core dating from the Portuguese colonial time surrounded by poorly organized neighborhoods. The original settlements of the two cities were placed on or very close to the Catumbela delta, both owing their locations to favorable natural conditions. Lobito is near the continental end of a $5 \mathrm{~km}$ long sand spit that constitutes a natural protection for the city bay [43], hence allowing the development of the second most important harbor of Angola. Catumbela is at the northern margin of Catumbela River where it leaves its incised valley and enters the fertile but periodically inundated delta plain. The construction of the Benguela Railway and the harbor of Lobito (early 20th century) played a fundamental role for the later growth of both cities. The National Statistics Institute, based on the census conducted in 2014, estimated $\sim 394,000$ inhabitants for the municipality of Lobito and $\sim 176,000$ inhabitants for Catumbela [44]. Population is expected to increase by more than $20 \%$ in the following 10 years [45].

During recent decades, several neighborhoods emerged and grew rapidly in the hills to the east of these cities. In 1972, heavy rains, responsible for the flooding of occupied lowland mangroves of Lobito, enhanced the human displacement to the neighboring areas at higher elevation. Growing rates of Lobito and Catumbela accelerated during the last quarter of the 20th century due to the civil war, starting in 1975, giving rise to numerous disordered housing nuclei at the slopes and valleys to the east and north of the cities' cores (Figure 2). The streets in these informal settlements are not paved, there are no drainage structures and the houses are frequently made with cheap construction material and rudimentary technology. Houses built of adobe bricks and roofed by zinc sheets weight-attached with boulders deposited on them are widespread in these settlements. 

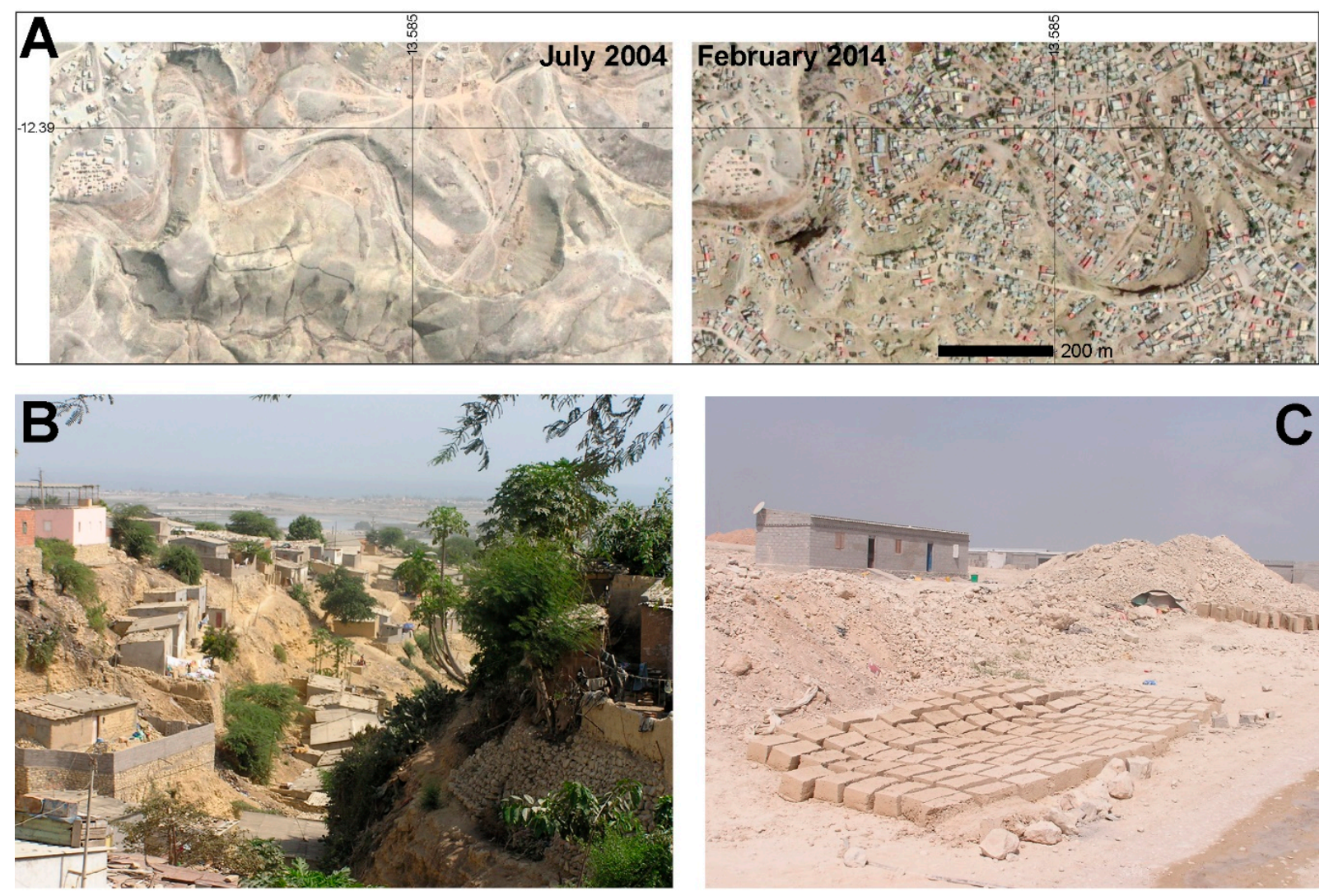

Figure 2. Human occupation in the dry valleys of coastal Benguela increased rapidly during recent decades. The catchment most affected by the flooding event of 2015 is a good example where the early $2000 \mathrm{~s}$ saw the appearance of many houses in coastal hills (A) Google Earth ${ }^{\mathrm{TM}}$ images. (B) Examples of the recent settlements in hills surrounding Lobito. (C) Adobe bricks, the cheapest and easiest to obtain construction material in the disordered burghs of Lobito and Catumbela.

\section{Methods}

A generalized workflow for the present investigation is presented in Figure 3. A Digital Elevation Model (DEM; 10 m resolution), based on SPOT (Satellite Pour l'Observation de la Terre) images, was processed for surface analyses, namely the geomorphological characterization of the coastal region and individual catchments. For the delimitation of drainage areas, DEM data were processed with the Hydrology tool package of ArcGIS. Data retrieved from the DEM were also adopted for the computation of general morphometric parameters of the drainage basins (Table 1). These include the average and maximum slope, relief ratio (Rh), form factor (Rf) [46] and the circulatory ratio (Rc) [47].

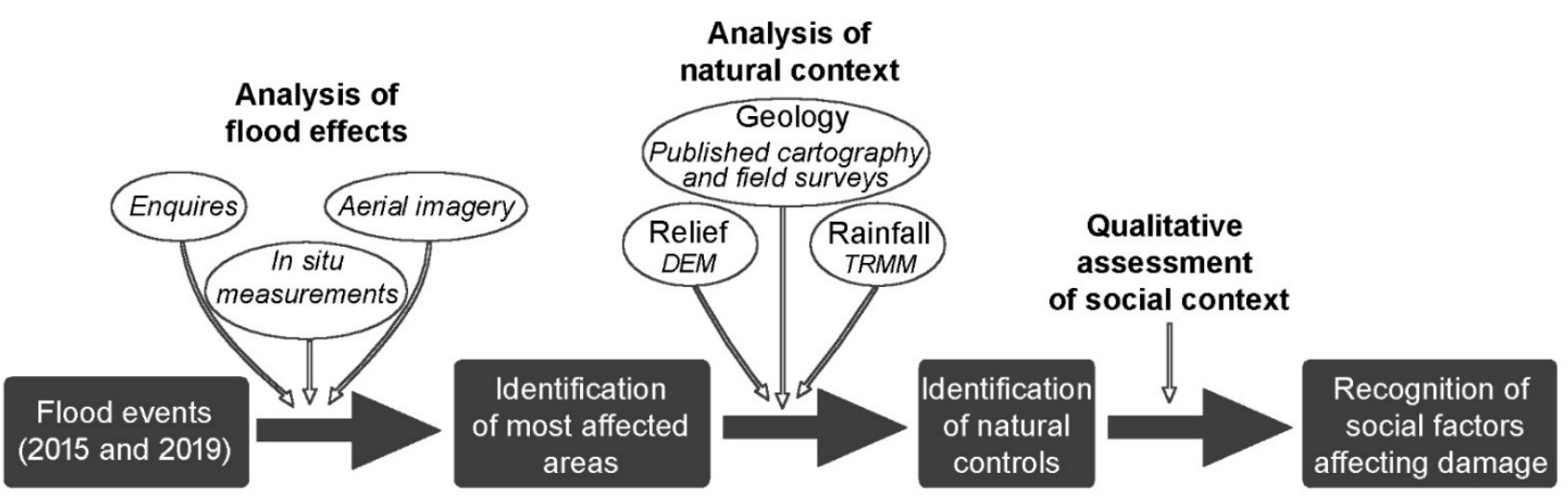

Figure 3. Workflow adopted to establish the causes of the flash flood damage in coastal Benguela. 
Table 1. General geomorphological features of the studied catchments.

\begin{tabular}{ccccc}
\hline Parameter & Formula & BW1 & BW2 & Regional Range \\
\hline $\mathrm{Rh}$ & $\mathrm{H} / \mathrm{Lb}$ & 0.045 & 0.078 & $0.045-0.111$ \\
$\mathrm{Rf}$ & $\mathrm{A} / \mathrm{Lb}^{2}$ & 0.24 & 0.43 & $0.15-0.64$ \\
$\mathrm{Rc}$ & $4^{*} \mathrm{pi} \times \mathrm{A} / \mathrm{P}^{2}$ & 0.37 & 0.45 & $0.24-0.45$ \\
Aver. Slope $(\%)$ & & 14.7 & 25.8 & $13.7-24.4$ \\
Max. slope $(\%)$ & & 93.9 & 103.5 & $93.9-120.3$ \\
Length $(\mathrm{km})$ & & 7.76 & 2.39 & $2.39-7.76$ \\
Area $(\mathrm{ha})$ & & 1563 & 244 & $244-1563$ \\
\hline
\end{tabular}

H: total relief; Lb: catchment length; A: area; P: perimeter.

Due to the limitations of weather data for the Angolan territory, TRMM (Tropical Rainfall Measuring Mission) Multi-satellite Precipitation Analysis (TMPA) was used for rainfall estimates. Data were derived from Multi-satellite Precipitation Analysis products, available at the TRMM Online Visualization and Analysis System TOVAS [48]. Rainfall results were retrieved from four tiles, each with $0.25^{\circ}$ latitude $\times 0.25^{\circ}$ longitude (i.e., $\sim 27 \mathrm{~km}$ side) that enclose the drainage basins severely affected by the flooding events of 2015 and 2019. Daily data, with $3 \mathrm{~h}$ intervals, were obtained from the archived products 3B42 v7. These rainfall estimates are ranked among the best derived from remote products for the African continent [49].

Field work was carried out during the four weeks following the events of March 2015 and 2019. Affected areas were surveyed to identify and measure flooding effects and questionnaires were delivered to local residents in order to gather data on the flooding dynamics during the events. Enquired people were asked to show in situ references that could be used to establish water levels and how it evolved through time. Only maximum water levels were consistently indicated by locals. Flood depths were then measured in reference to the closest valley bottom. After the field-identification of the most affected areas, the flooding effects was confirmed with the analysis of satellite images available through Google Earth ${ }^{\mathrm{TM}}$ for the periods immediately before and after the events. Flood heights during the two events were launched on the DEM to establish inundated areas and possible sites of flow constrain.

\section{Results}

\subsection{Flash Flood of March 2015 (Lobito)}

After the end of the dry season, a few very minor rainfall events, never reaching $2 \mathrm{~mm}$ of daily precipitation, occurred until mid-February (Figure 4). More intense rainfall is recorded for 22-24 February and 4 March, with near $10 \mathrm{~mm}$. The rainfall event of March 9 started by 19:00 and an accumulated $\sim 12 \mathrm{~mm}$ was reached in $3 \mathrm{~h}$, triggering a flash flood. According to TRMM data, no rain fell in the $3 \mathrm{~h}$ preceding or following this event.

This flash flood caused enormous disturbance and changed local landscape (Figure 5). Major damage concentrated in a small coastal catchment $\left(15.63 \mathrm{~km}^{2}\right.$; BW1 in Figure 1 and Table 1), which feeds an artificial channel running at the contact between the Catumbela delta and the Cretaceous outcrops of the Benguela Basin. This artificial channel plays a fundamental role for urban drainage, receiving the waters from the elevated zones of Lobito. The affected catchment is elongated E-W, stretching for $\sim 7.5 \mathrm{~km}$ and reaching $360 \mathrm{~m}$ in elevation. Reflecting its elongated character, $\mathrm{Rf}$ and Rc are relatively low (Table 1). With an average slope of $\sim 15 \%$, the catchment displays sectors with contrasting gradients. Namely, a deeply incised region draining the marly Quissonde Formation and the transition to the underlying Catumbela Formation, and an overall flatter sector with sandy carbonates of the Catumbela Formation. 

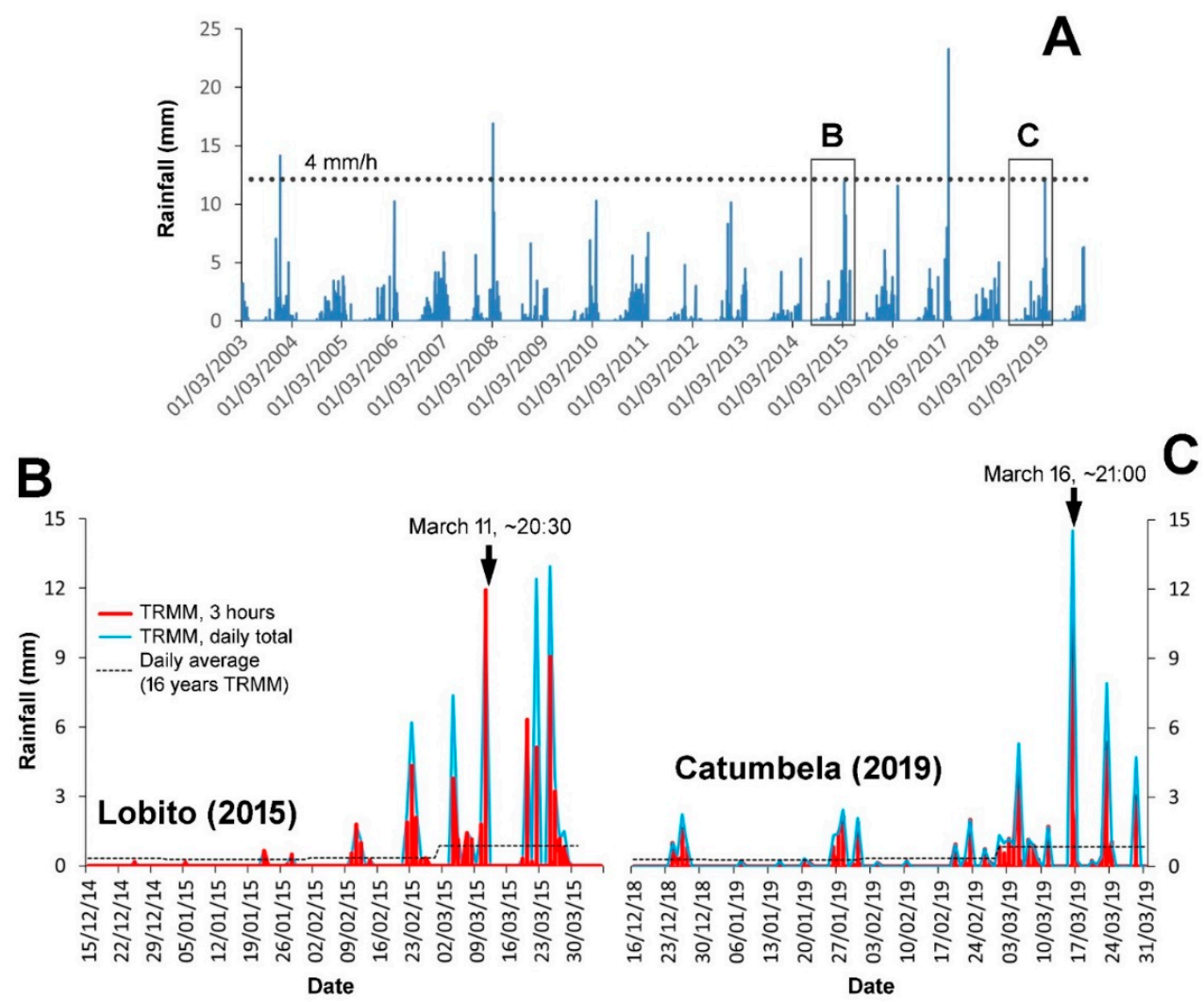

Figure 4. TRMM data for the studied region. Aerial rainfall averages for available hydrological years (A), and for the flooding events of 2015 in Lobito (B) and 2019 in Catumbela (C). Black arrows indicate flash flood dates. Daily averages for different months obtained with the available TRMM data.
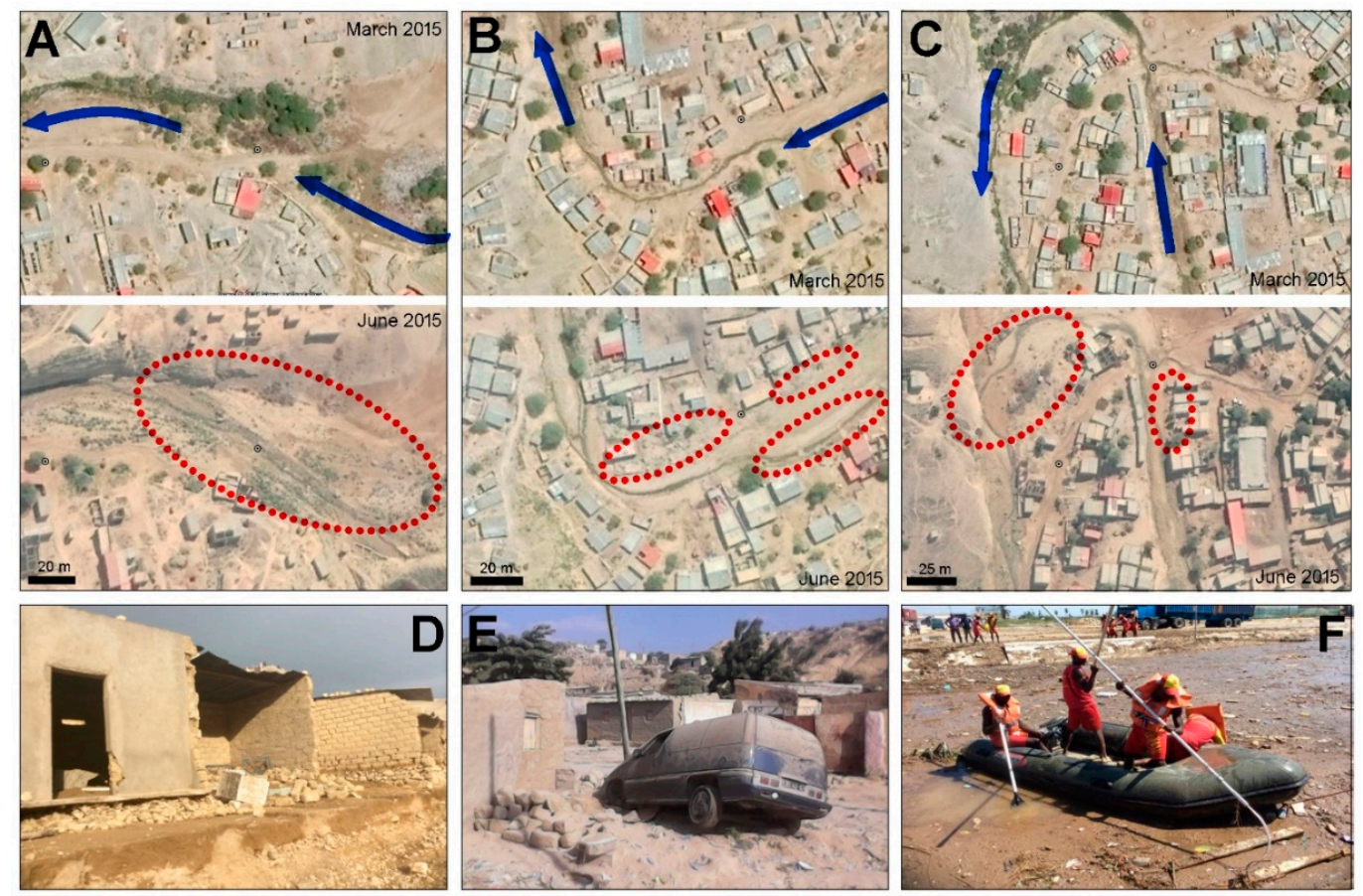

Figure 5. Images illustrating the effects of the 2015 floods. (A-C) Urban landscape changes due to the flash flood in a recently occupied area; arrows in upper panels indicate flow direction and the ellipses in the lower panel indicate areas with unrooted trees and collapsed houses. (D) Houses partially destroyed during the flood. (E) A car dragged by the current against a collapsed house. (F) Firefighters in the artificial drainage channel plugged with sediment and house-hold debris looking for flood victims. Satellite images from Google Earth ${ }^{\mathrm{TM}}$. 
The highest water levels were reached in two sectors of this catchment (Figure 6). The western sector is immediately upstream of the point where the natural catchments reach the artificial drainage channel, near Lobito stadium; here the water level attained $\sim 2 \mathrm{~m}$ above valley bottoms in several locations, decreasing progressively inland. (2) The eastern sector is approximately $3 \mathrm{~km}$ upstream, at the bottom of a sinuous valley, which had almost no buildings in early 2000 but where human occupation grew rapidly during recent decades (Figure 2); as in the westerns sector, water levels rose $\sim 2 \mathrm{~m}$. The flood also affected the region downstream of Lobito stadium due to the obstruction of the artificial drainage channel with solid waste (plastics, vegetable remains, scraps, etc.), which caused overflow to the housing structures in the Catumbela delta.

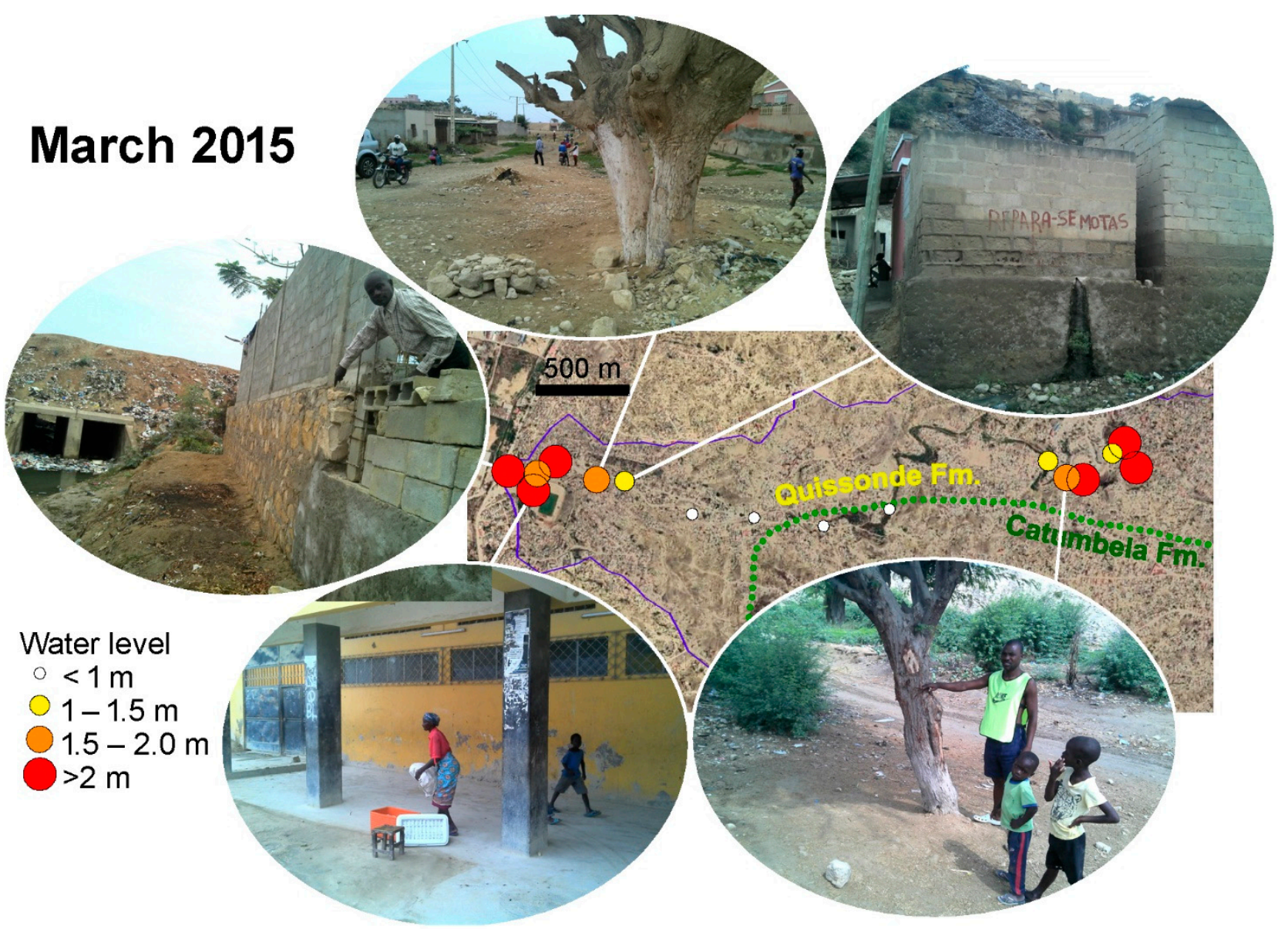

\section{March 2019}

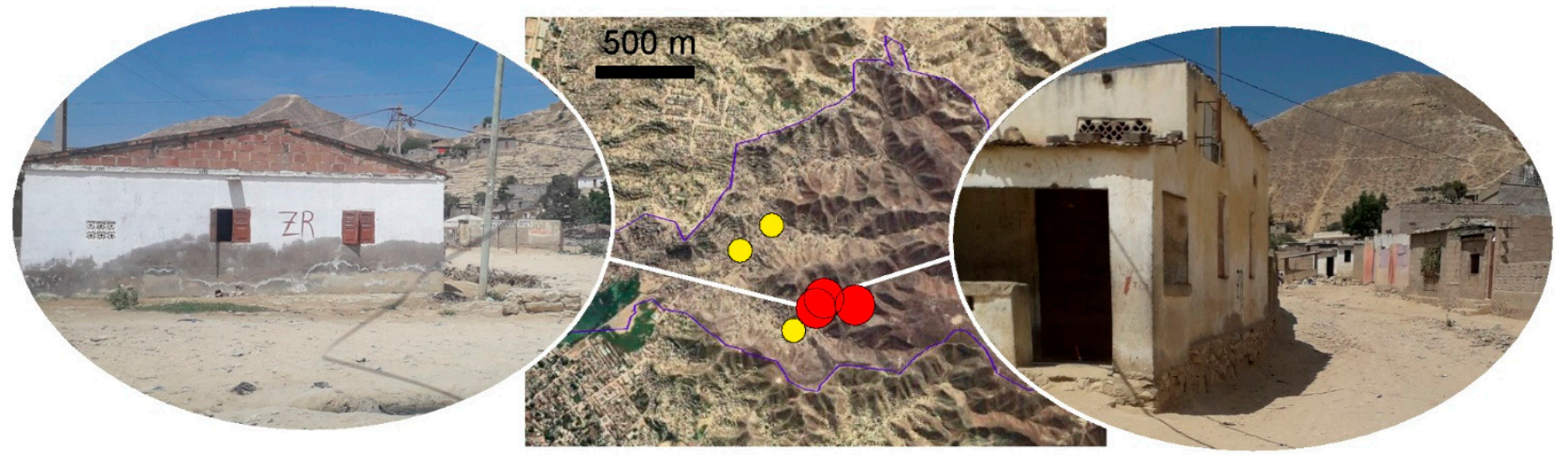

Figure 6. Water levels reached in the drainage areas most affected by the flash floods of 2015, in the outskirts of Lobito, and 2019, in Catumbela. The catchment most affected by the 2019's event is entirely in Quissonde Formation. 


\subsection{Flash Flood of March 2019 (Catumbela)}

Meteorological conditions associated with the event of 2019 resemble those of 2015 (Figure 4). The flash flood was triggered by a rainstorm on March 16 responsible for $\sim 12 \mathrm{~mm}$ precipitation in $3 \mathrm{~h}$, which occurred after an early wet season with minor precipitation. Rainfall persisted for relatively longer time than observed in the 2015's event, lasting until the end of the day, but then with substantially lower volumes.

Although not exclusively in this area, damage was concentrated in the catchment of a very minor coastal tributary of Catumbela River $\left(2.44 \mathrm{~km}^{2}\right.$; Figure 1 and Table 1$)$. This small catchment has relatively circular shape $(\mathrm{Rf}=0.43 ; \mathrm{Rc}=0.45)$ and displays an average slope of 26\% (Table 1). It drains exclusively the uplifted Quissonde Formation to the east of the Catumbela delta. Water levels also reached approximately $2 \mathrm{~m}$ above valley bottom in recently occupied sinuous stream stretches (Figure 6).

\section{Discussion}

\subsection{Natural Features Promoting Flash Floods}

Several geomorphological features favor runoff and limit infiltration in the regions of coastal Benguela affected by the flash floods. First of all, in the small drainage basins where damage was higher crop out poorly consolidated fine-grained rocks that tend to be impermeable. A dense drainage net dissecting these uplifted units accounts for the prevalence of relatively steep slopes, which also favor surface runoff. In addition, dry climates limit vegetation cover and soil development that act as flood buffers retaining water and limiting rapid runoff. It has been recognized that the presence of vegetation and non-impervious soils has clear positive effects limiting runoff velocities and the flood magnitudes [14,16]. Therefore, the coastal Benguela region with relatively steep exposures of fine-grained Cretaceous units and almost bare of vegetation cover is highly vulnerable to flash floods. Flooding heights are also determined by valley bottom topography, which is partially determined by lithological heterogeneities. Not unusually, indurated limestone layers are elevated relative to adjacent more friable marls, and a discernible longitudinal relief is present where streams run parallel to dip direction. The location of some areas with high flooding levels may have been partially controlled by these structural features (Figure 7).

On the other hand, the overall shape of the basins cannot be considered a major hazardous factor. In general, elongated watersheds with low form factor and circulatory ratios have lower peak flow of longer duration $[12,13]$. However, the damage produced by 2015 's flood concentrated in a clearly elongated catchment, while comparable regional catchments (Table 1), which received similar rain, were not severely affected.

Recent climate change is a major matter of concern when dealing with flood risks [50-57]. Extreme rainfall events tend to be associated with the most hazardous low frequency floods [58-60] and significant increases in flooding depths, considering different climatic scenarios, have been proposed for various world regions [52,57]. Some authors projected that global warming will be responsible for more extreme rainfall events in a drier southern Africa $[50,61]$. Others, however, defended the idea that shifts in climatic variables during recent decades were not crucial for the increasing flood-related damage [22].

Regarding the investigated flash floods of 2015 and 2019, the approximately $4 \mathrm{~mm} / \mathrm{h}$ precipitation associated these events are not particularly high. Although $99.95 \%$ of the 3-h records for the humid season (November to April) are below $11.5 \mathrm{~mm}$, this value should not be considered a threshold for flash flood triggering. Such a rain amount was reached in 6 out of 16 hydrologic years (2003-2019), and was even doubled once (on 11 April 2017, $23.3 \mathrm{~mm}$ ) without causing major damage (Figure 4). As estimates derived from 3B42 for heavy rain events tend to be underestimated e.g., [62], some local convective rain may have not been detected with the adopted TRMM data. However, the bias relative to actual rainfall tends to be lower in dry and low elevation regions [63,64], and a significant underestimation is less likely where daily rainfall ranges $0.5-25 \mathrm{~mm}$ [65]. Hence, it can be considered that the rain rates associated with the two events that affected coastal Benguela 
were not substantially higher than $4 \mathrm{~mm} / \mathrm{h}$, suggesting that other factors must have been involved in the development of the hazardous flash floods.
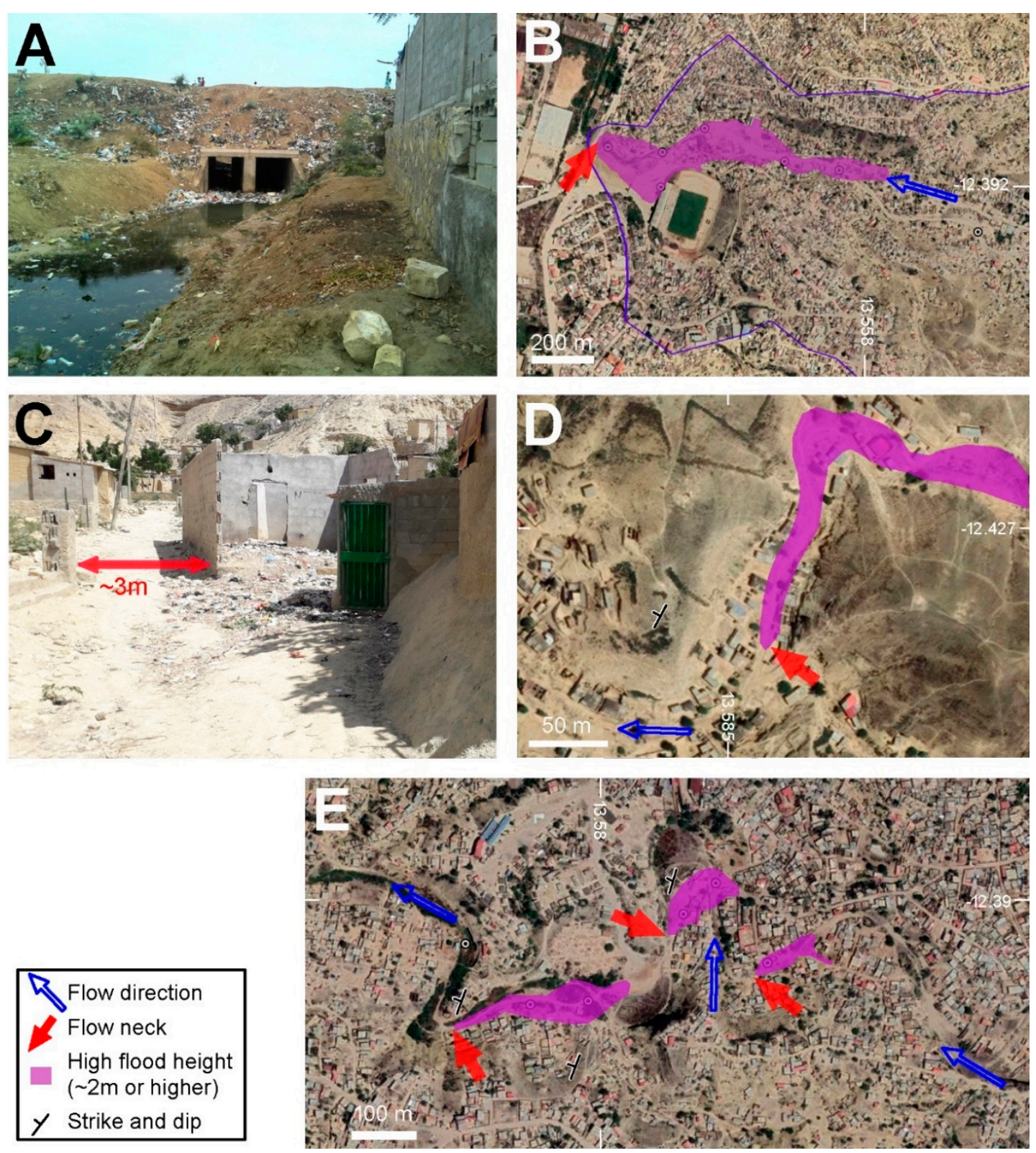

Figure 7. Identification of sites of flow constraint and high flood height. (A) The drain connecting the most affected stream catchment during the 2015's event with the artificial channel for urban drainage with abundant plastic detritus. (B) Water levels at the valley bottom for several hundred meters upstream of this point were close to $2 \mathrm{~m}$. (C) A narrow street, locally less than $3 \mathrm{~m}$ in width, where several human structures collapsed during the 2019 event. (D) The site show in (C) and the upstream valley stretch with high flood height. (E) A recently occupied area where several houses collapsed during the 2015's event; high-water levels were reached in discrete valley stretches. Satellite images from Google Earth ${ }^{\mathrm{TM}}$.

\subsection{Socio-Economic Factors Enhancing Flood Risk}

Factors linked with the absolute number and the proportion of population residing in informal settlements of flood-prone areas are probably the most important for flood damage in the African continent [22]. Because of the rapid and uncontrolled urban sprawl, a considerable proportion of the population of Lobito and Catumbela lives in hazardous areas, namely on the slopes and beds of dry rivers. Due to extreme poverty, houses were built with poor quality materials and rudimentary techniques. Narrow streets can hamper 
water flow (Figure 7C) and downstream flow constrains are probably enhanced after the collapse of vulnerable buildings.

The construction on compacted dirt streets that developed on fine-grained geological units increased substantially the proportion of impervious surfaces. Some houses were located near the old flood dikes and promoted their degradation, complicating water drainage [31]. In addition, unplanned groundworks increased the topographic irregularities of the dry valley bottoms that may result in local drainage constrains. Small discrete areas where the water attained high levels in a recently occupied area are explained by topographic irregularities created this way (Figure 7E).

Waste debris, in particular plastics and other voluminous materials that display high floatability due to their density and shape, enhance flooding hazards by contributing to blocking drainage channels [66-68]. The blockage by plastic appears to be much faster than by organic materials [69], hence effectively increasing flooding risks in areas where this type of wastes is abundant and not properly managed. The influence of plastic waste on flood hazards, namely in developing African countries where routine assessments of this type of pollution are still lacking [70], is a sensitive issue that needs further investigation. In major cities of Benguela Province, voluminous debris and litter accumulate along the drainage channels, especially during dry season when almost no water flows through them. The subsequent rain events are responsible for the mobilization of great amount of wastes that compromise water drainage in bottleneck points and promote sudden rises in water levels. The accumulation of floatable debris was particularly obvious at the downstream end of the stream most affected by the 2015's flash floods (Figure 7A).

An additional factor is the risk perception by the residents in the affected areas. Previous works have shown that those that live near a river are more likely to acknowledge flood hazard e.g., [71]. The population that occupies the dry hills surrounding Catumbela river and delta do not see reasons to consider that those areas pose some flooding hazard. Instead, a major source of concern is water scarcity.

\section{Concluding Remarks}

The rain rates that triggered the flash flood events of 2015 and 2019 were relatively low $(\sim 4 \mathrm{~mm} / \mathrm{h})$. Substantially higher rainfall commonly occurs in many regions of Angola and other countries with comparable socio-economic conditions without the dramatic effects observed in coastal Benguela. The natural setting, characterized by small streams draining uplifted fine-grained sedimentary units with a dense fluvial net, very thin soils and minor vegetation cover, limits infiltration and promotes runoff. However, the main factors responsible for major damage are socio-economic. They result from the rapid and unplanned occupation, frequently with vulnerable houses, the absence or degradation of drainage structures, the high waste yields that are not properly managed, and the unawareness of the flash flood hazard.

Disastrous floods in coastal Benguela can thus be triggered by moderate or even minor rainfall. Damage likely occurs very shortly after peak rainfall $(<1 \mathrm{~h})$, and the timing and affected areas are hard to accurately predict. The occurrence of major damage in some fluvial stretches is determined by local positive feedback mechanisms. For example, after flow paths become obstructed at some point with wastes carried by surface runoff, the rise in water level may promote the collapse of vulnerable buildings, which increases the amount of detritus in transit further compromising water flow. After the breaching of drainage constraints created that way, a major flood wave will travel downstream. Under these environmental conditions, the best measures to effectively cope with flash flood risks are probably those focused on the reduction of local human-generated factors.

Author Contributions: Conceptualization, P.A.D.; methodology, P.A.D. and J.H.; software, P.A.D. and M.C.P.; validation, P.A.D. and J.H.; formal analysis, P.A.D., J.H., M.C.P. and J.C.; investigation, P.A.D., J.H., M.C.P. and J.C.; resources, P.A.D. and J.H.; data curation, P.A.D. and J.C.; writingoriginal draft preparation, P.A.D.; visualization, P.A.D. and M.C.P.; supervision, P.A.D.; project 
administration, P.A.D. and J.H. All authors have read and agreed to the published version of the manuscript.

Funding: This research was supported by national funds through FCT - Foundation for Science and Technology, I.P., within the scope of the projects UIDB/04292/2020 (MARE) and UIDB/04035/2020 (GeoBioTec).

Data Availability Statement: Publicly available datasets were analyzed in this study. These data can be found here: https://trmm.gsfc.nasa.gov/ (accessed on 1 April 2021). The remaining data are available in the manuscript.

Acknowledgments: The Municipality of Lobito (Administração Municipal do Lobito) provided detailed information, including reports and pictures, that were fundamental to understand the damage caused by the flood of 2015. The authors are grateful for the comments and suggestions made by three anonymous reviewers that helped to improve the article.

Conflicts of Interest: The authors declare no conflict of interest.

\section{References}

1. United Nations. The Human Cost of Weather-Related Disaters. 1995-2015; United Nations Office for Disaster Risk Reduction: Genève, Switzerland, 2015.

2. Smith, K.; Ward, R. Floods: Physical Processes and Human Impacts; Wiley: Chichester, UK, 1998.

3. Montz, B.E.; Gruntfest, E. Flash flood mitigation: Recommendations for research and applications. Glob. Environ. Chang. Part B 2002, 4, 15-22. [CrossRef]

4. Bubeck, P.; Botzen, W.J.W.; Aerts, J.C. A review of risk perceptions and other factors that influence flood mitigation behavior. Risk Anal. 2012, 32, 1481-1495. [CrossRef]

5. Drobot, S.; Parker, D.J. Advances and challenges in flash flood warnings. Environ. Hazards 2007, 7, 173-178. [CrossRef]

6. Ramos Filho, G.M.; Coelho, V.H.R.; da Silva Freitas, E.; Xuan, Y.; das Neves Almeida, C. An improved rainfall-threshold approach for robust prediction and warning of flood and flash flood hazards. Nat. Hazards 2020, 105, 2409-2429. [CrossRef]

7. Zaman, M.A.; Rahman, A.; Haddad, K. Regional flood frequency analysis in arid regions: A case study for Australia. J. Hydrol. 2012, 475, 74-83. [CrossRef]

8. Bajabaa, S.; Masoud, M.; Al-Amri, N. Flash flood hazard mapping based on quantitative hydrology, geomorphology and GIS techniques (case study of Wadi Al Lith, Saudi Arabia). Arab. J. Geosci. 2014, 7, 2469-2481. [CrossRef]

9. Zhang, J.; Yu, Z.; Yu, T.; Si, J.; Feng, Q.; Cao, S. Transforming flash floods into resources in arid China. Land Use Policy 2018, 76, 746-753. [CrossRef]

10. Hadihardaja, I.K.; Vadiya, R. Identification of flash flood hazard zones in mountainous small watershed of Aceh Besar Regency, Aceh Province, Indonesia. Egyp. J. Remote Sens. Space Sci. 2016, 19, 143-160.

11. Bui, D.T.; Hoang, N.D.; Pham, T.D.; Ngo, P.T.T.; Hoa, P.V.; Minh, N.Q.; Tran, X.-T.; Samui, P. A new intelligence approach based on GIS-based multivariate adaptive regression splines and metaheuristic optimization for predicting flash flood susceptible areas at high-frequency tropical typhoon area. J. Hydrol. 2019, 575, 314-326.

12. Howard, A.D. Role of hypsometry and planform in basin hydrologic response. Hydrol. Process. 1990, 4, 373-385. [CrossRef]

13. Youssef, A.M.; Pradhan, B.; Hassan, A.M. Flash flood risk estimation along the St. Katherine road, southern Sinai, Egypt using GIS based morphometry and satellite imagery. Environ. Earth Sci. 2011, 62, 611-623. [CrossRef]

14. Nicolau, J.M.; Solé-Benet, A.; Puigdefábregas, J.; Gutiérrez, L. Effects of soil and vegetation on runoff along a catena in semi-arid Spain. Geomorphology 1996, 14, 297-309. [CrossRef]

15. Cras, A.; Marc, V.; Travi, Y. Hydrological behaviour of sub-Mediterranean alpine headwater streams in a badlands environment. J. Hydrol. 2007, 339, 130-144. [CrossRef]

16. Yang, J.L.; Zhang, G.L. Water infiltration in urban soils and its effects on the quantity and quality of runoff. J. Soils Sediments 2011, 11, 751-761. [CrossRef]

17. Kang, I.S.; Park, J.I.; Singh, V.P. Effect of urbanization on runoff characteristics of the On-Cheon Stream watershed in Pusan, Korea. Hydrol. Process. 1998, 12, 351-363. [CrossRef]

18. Booth, D.B.; Hartley, D.; Jackson, R. Forest cover, impervious-surface area, and the mitigation of stormwater impacts. J. Am. Water Resour. Assoc. 2002, 38, 835-845. [CrossRef]

19. Smith, J.A.; Baeck, M.L.; Meierdiercks, K.L.; Nelson, P.A.; Miller, A.J.; Holland, E.J. Field studies of the storm event hydrologic response in an urbanizing watershed. Water Resour. Res. 2005, 41. [CrossRef]

20. Todeschini, S. Hydrologic and environmental impacts of imperviousness in an industrial catchment of northern Italy. J. Hydrol. Eng. 2016, 21. [CrossRef]

21. Sanderson, D. Cities, disasters and livelihoods. Risk Manag. 2000, 2, 49-58. [CrossRef]

22. Di Baldassarre, G.; Montanari, A.; Lins, H.; Koutsoyiannis, D.; Brandimarte, L.; Blöschl, G. Flood fatalities in Africa: From diagnosis to mitigation. Geophys. Res. Lett. 2010, 37. [CrossRef]

23. Gupta, A.K.; Nair, S.S. Flood risk and context of land-uses: Chennai city case. J. Geogr. Reg. Plan. 2010, 3, 365-372. 
24. De Risi, R.; Jalayer, F.; De Paola, F.; Iervolino, I.; Giugni, M.; Topa, M.E.; Gasparini, P. Flood risk assessment for informal settlements. Nat. Hazards 2013, 69, 1003-1032. [CrossRef]

25. Hoedjes, J.C.; Kooiman, A.; Maathuis, B.H.; Said, M.Y.; Becht, R.; Limo, A.; Mumo, M.; Nduhiu-Mathenge, J.; Shaka, A.; Su, B. A conceptual flash flood early warning system for Africa, based on terrestrial microwave links and flash flood guidance. ISPRS Int. J. Geo Inf. 2014, 3, 584-598. [CrossRef]

26. Jubach, R.; Tokar, A.S. International severe weather and flash flood hazard early warning systems-Leveraging coordination, cooperation, and partnerships through a hydrometeorological project in Southern Africa. Water 2016, 8, 258. [CrossRef]

27. Clark, R.A.; Flamig, Z.L.; Vergara, H.; Hong, Y.; Gourley, J.J.; Mandl, D.J.; Frye, S.; Handy, M.; Patterson, M. Hydrological modeling and capacity building in the Republic of Namibia. Bull. Am. Meteorol. Soc. 2017, 98, 1697-1715. [CrossRef]

28. De Coning, E. Optimizing satellite-based precipitation estimation for nowcasting of rainfall and flash flood events over the South African domain. Remote Sens. 2013, 5, 5702-5724. [CrossRef]

29. Dinis, P.A.; Mantas, V.; Andrade, P.S.; Tonecas, J.; Kapula, E.; Pereira, A.; Carvalho, F.S. Contribution of TRMM rainfall data to the study of natural systems and risk assessment. Cases of application in SW Angola. Quat. Stud. 2013, 9, 33-43. [CrossRef]

30. Bangira, T.; Maathuis, B.H.; Dube, T.; Gara, T.W. Investigating flash floods potential areas using ASCAT and TRMM satellites in the Western Cape Province, South Africa. Geocarto Int. 2015, 30, 737-754. [CrossRef]

31. AML. Relatório Sobre as Calamidades de 11 a 25 de Março; Unpublished Report; Administração Municipal do Lobito: Lobito, Angola, 2015.

32. Guiraud, M.; Buta-Neto, A.; Quesne, D. Segmentation and differential post-rift uplift at the Angola margin as recorded by the transform-rifted Benguela and oblique-to-orthogonal-rifted Kwanza basins. Mar. Pet. Geol. 2010, 27, 1040-1068. [CrossRef]

33. Neto, M.G.M. O sedimentar costeiro de Angola. Algumas notas sobre o estado actual do seu conhecimento. Junta Investig. Ultramar 1970, 2, 193-232.

34. Buta-Neto, A.; Tavares, T.S.; Quesne, D.; Guiraud, M.; Meister, C.; David, B.; Duarte-Morais, M.L. Synthèse préliminaire des travaux menés sur le bassin de Benguela (Sud Angola): Implications sédimentologiques, paléontologiques et structurales. Afr. Geosci. Rev. 2006, 13, 239-250.

35. Dinis, P.A.; Huvi, J.; Callapez, P.M. The Catumbela delta (SW Angola). Processes determining a history of changing asymmetry. J. Afr. Earth Sci. 2018, 145, 68-79. [CrossRef]

36. Nicholson, S.E.; Entekhabi, D. Rainfall variability in equatorial and southern Africa: Relationships with sea surface temperatures along the southwestern coast of Africa. Bull. Am. Meteorol. Soc. 1987, 26, 561-578. [CrossRef]

37. Leroux, M. Dynamic Analysis of Weather and Climate: Atmospheric Circulation, Perturbations, Climatic Evolution; John Wiley \& Sons: Hoboken, NJ, USA, 1998.

38. Lancaster, N. How dry was dry?-Late Pleistocene palaeoclimates in the Namib Desert. Quat. Sci. Rev. 2002, 21, 769-782. [CrossRef]

39. Shannon, L.V.; Boyd, A.J.; Brundrit, G.B.; Taunton-Clark, J. On the existence of an El Niño-type phenomenon in the Benguela system. J. Mar. Res. 1986, 44, 495-520. [CrossRef]

40. Florenchie, P.; Lutjeharms, J.R.E.; Reason, C.J.C.; Masson, S.; Rouault, M. The source of Benguela Ninos in the South Atlantic Ocean. Geophys. Res. Lett. 2003, 30, 1505. [CrossRef]

41. Rouault, M.; Illig, S.; Bartholomae, C.; Reason, C.J.C.; Bentamy, A. Propagation and origin of warm anomalies in the Angola Benguela upwelling system in 2001. J. Mar. Syst. 2007, 68, 473-488. [CrossRef]

42. Imbol Koungue, R.A.; Rouault, M.; Illig, S.; Brandt, P.; Jouanno, J. Benguela Niños and Benguela Niñas in forced ocean simulation from 1958 to 2015. J. Geophys. Res. Ocean. 2019, 124, 5923-5951. [CrossRef]

43. Dinis, P.A.; Huvi, J.; Cascalho, J.; Garzanti, E.; Vermeesch, P.; Callapez, P. Sand-spits systems from Benguela region (SW Angola). An analysis of sediment sources and dispersal from textural and compositional data. J. Afr. Earth Sci. 2016, 117, 171-182. [CrossRef]

44. INE. Resultados Definitivos, Recenseamento Geral da População e Habitação-2014, Província de Benguela; Instituto Nacional de Estatística: Luanda, Angola, 2016.

45. INE. Projeção da População da Província de Benguela; Instituto Nacional de Estatística: Luanda, Angola, 2016.

46. Horton, R.E. Drainage-basin characteristics. EOS Trans. Am. Geophys. Union 1932, 13, 350-361. [CrossRef]

47. Miller, V.C. A Quantitative Geomorphic Study of Drainage Basin Characteristics in the Clinch Mountain Area Virginia and Tennessee; Columbia University: New York, NY, USA, 1953.

48. Liu, Z.; Ostrenga, D.; Teng, W.; Kempler, S. Tropical Rainfall Measuring Mission (TRMM) Precipitation Data and Services for Research and Applications. Bull. Am. Meteorol. Soc. 2012, 99, 1317-1325. [CrossRef]

49. Awange, J.L.; Ferreira, V.G.; Forootan, E.; Andam-Akorful, S.A.; Agutu, N.O.; He, X.F. Uncertainties in remotely sensed precipitation data over Africa. Int. J. Clim. 2016, 36, 303-323. [CrossRef]

50. Mason, S.J.; Joubert, A.M. Simulated changes in extreme rainfall over southern Africa. Int. J. Climatol. 1997, 17, 291-301. [CrossRef]

51. Bronstert, A. Floods and climate change: Interactions and impacts. Risk Anal. 2003, 23, 545-557. [CrossRef]

52. Mirza, M.M.Q.; Warrick, R.A.; Ericksen, N.J. The implications of climate change on floods of the Ganges, Brahmaputra and Meghna rivers in Bangladesh. Clim. Chang. 2003, 57, 287-318. [CrossRef]

53. Kundzewicz, Z.W.; Kanae, S.; Seneviratne, S.I.; Handmer, J.; Nicholls, N.; Peduzzi, P.; Mechler, R.; Bouwer, L.M.; Arnell, N.; Mach, K.; et al. Flood risk and climate change: Global and regional perspectives. HSJ 2014, 59, 1-28. [CrossRef] 
54. Billi, P.; Alemu, Y.T.; Ciampalini, R. Increased frequency of flash floods in Dire Dawa, Ethiopia: Change in rainfall intensity or human impact? Nat. Hazards 2015, 76, 1373-1394. [CrossRef]

55. Arnell, N.W.; Gosling, S.N. The impacts of climate change on river flood risk at the global scale. Clim. Chang. 2016, 134, 387-401. [CrossRef]

56. Sylla, M.B.; Nikiema, P.M.; Gibba, P.; Kebe, I.; Klutse, N.A.B. Climate change over West Africa: Recent trends and future projections. In Adaptation to Climate Change and Variability in Rural West Africa; Yaro, J.A., Hesselberg, J., Eds.; Springer International Publishing: Cham, Switzerland, 2016; pp. 25-40.

57. Zhang, Y.; Wang, Y.; Chen, Y.; Liang, F.; Liu, H. Assessment of future flash flood inundations in coastal regions under climate change scenarios-A case study of Hadahe River basin in northeastern China. Sci. Total Environ. 2019, 693, 133550. [CrossRef]

58. Borga, M.; Stoffel, M.; Marchi, L.; Marra, F.; Jakob, M. Hydrogeomorphic response to extreme rainfall in headwater systems: Flash floods and debris flows. J. Hydrol. 2014, 518, 194-205. [CrossRef]

59. Duan, W.; He, B.; Takara, K.; Luo, P.; Nover, D.; Yamashiki, Y.; Huang, W. Anomalous atmospheric events leading to Kyushu's flash floods. Nat. Hazards 2014, 73, 1255-1267. [CrossRef]

60. Bryndal, T.; Franczak, P.; Kroczak, R.; Cabaj, W.; Kołodziej, A. The impact of extreme rainfall and floods on the flood risk management process and geomorphological changes in small Carpathian catchments: A case study of the Kasiniczanka river (Outer Carpathians, Poland). Nat. Hazards 2017, 88, 95-120. [CrossRef]

61. Pohl, B.; Macron, C.; Monerie, P.A. Fewer rainy days and more extreme rainfall by the end of the century in Southern Africa. Sci. Rep. 2017, 7, 1-7. [CrossRef] [PubMed]

62. Li, N.; Wang, Z.; Chen, X.; Austin, G. Studies of general precipitation features with TRMM PR data: An extensive overview. Remote Sens. 2019, 11, 80. [CrossRef]

63. Moazami, S.; Golian, S.; Kavianpour, M.R.; Hong, Y. Comparison of PERSIANN and V7 TRMM Multi-satellite Precipitation Analysis (TMPA) products with rain gauge data over Iran. Int. J. Remote Sens. 2013, 34, 8156-8171. [CrossRef]

64. Chen, S.; Hong, Y.; Gourley, J.J.; Huffman, G.J.; Tian, Y.; Cao, Q.; Xue, X. Evaluation of the successive V6 and V7 TRMM multisatellite precipitation analysis over the Continental United States. Water Resour. Res. 2013, 49, 8174-8186. [CrossRef]

65. Chen, C.; Chen, Q.; Duan, Z.; Zhang, J.; Mo, K.; Li, Z.; Tang, G. Multiscale comparative evaluation of the GPM IMERG v5 and TRMM 3B42 v7 precipitation products from 2015 to 2017 over a climate transition area of China. Remote Sens. 2018, 10, 944. [CrossRef]

66. Njeru, J. The urban political ecology of plastic bag waste problem in Nairobi, Kenya. Geoforum 2006, 37, 1046-1058. [CrossRef]

67. Lamond, J.; Bhattacharya, N.; Bloch, R. The role of solid waste management as a response to urban flood risk in developing countries, a case study analysis. WIT Trans. Ecol. Environ. 2012, 159, 193-204.

68. Lebreton, L.; Andrady, A. Future scenarios of global plastic waste generation and disposal. Palgrave Commun. 2019, 5, 6. [CrossRef]

69. Honingh, D.; van Emmerik, T.; Uijttewaal, W.; Kardhana, H.; Hoes, O.; van de, N. Urban river water level increase through plastic waste accumulation at a rack structure. Front. Earth Sci. 2020, 8, 28. [CrossRef]

70. van Emmerik, T.; Schwarz, A. Plastic debris in rivers. Wiley Interdiscip. Rev. Water 2020, 7, e1398. [CrossRef]

71. Fordham, M.; Tunstall, S.; Penning-Rowsell, E.C. Choice and preference in the Thames Floodplain: The beginnings of a participatory approach? Landsc. Urban Plan. 1991, 20, 183-187. 